\title{
Cisplatin Liposomal
}

National Cancer Institute

\section{Source}

National Cancer Institute. Cisplatin Liposomal. NCI Thesaurus. Code C2502.

A synthetic formulation in which the antineoplastic agent cisplatin is encapsulated in lipids.

Cisplatin liposomal consists of small aggregates of cisplatin covered by a single lipid bilayer. Encasement in liposomes improves cisplatin's tumor bioavailability and toxicity profile. Liposomal encapsulation does not affect the pharmacological properties of cisplatin directly. Cisplatin forms highly reactive, charged, platinum complexes which bind to nucleophilic groups such as GC-rich sites in DNA, inducing intrastrand and interstrand DNA cross-links, as well as DNA-protein cross-links. These cross-links result in apoptosis and cell growth inhibition. ( $\mathrm{NClO4})$ 